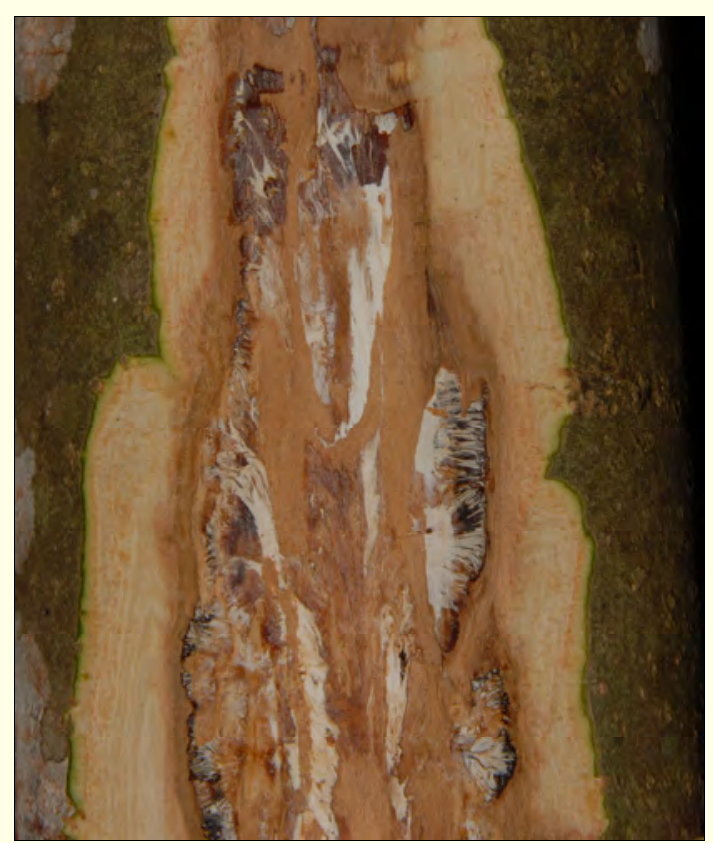

Slika 1: V skorji koreničnika velikega jesena se je razraščalo podgobje mraznice.

\title{
Revno rastišče in navadno ohmelje (Loranthus europaeus) je prizadelo graden na Dularjevem bregu pri Zidanem mostu
}

\section{Nikica OGRIS $^{1 *}$, Tine HAUPTMAN ${ }^{1}$, Tom LEVANIČ ${ }^{1}$, Dušan JURC ${ }^{1}$, Barbara SLABAN- JA $^{2}$, Boštjan PIHLER ${ }^{3}$}

Ob ogledu gozda na Dularjevem bregu pri Zidanem mostu smo ugotovili, da je med drevesnimi vrstami najbolj poškodovan graden (Quercus petraea). Primaren razlog za poškodovanost gradna smo pripisali revnemu, toplemu in sušnemu rastišču. Sekundaren pomen pri propadanju gradna je imelo navadno ohmelje (Loranthus europaeus). Na posameznih gradnih smo opazili tudi več kot 10 grmov navadnega ohmelja (slika 1). Bolj kakor sami grmi so bili opazni zadebeljeni predeli na vejah v obliki bul, ki so dosegale velikost človeške glave. Iz teh zadebeljenih predelov vej so izraščali grmi navadnega ohmelja, ki so imeli premer tudi do $1 \mathrm{~m}$ (slika 2). Okužene veje so se sušile in lomile. Nekateri gradni so imeli že toliko odlomljenih vej, da so bili videti kot okleščeni (slika 3).

Navadno ohmelje je 0,3-0,5 m (včasih do $1 \mathrm{~m}$ ) velik polparazitski grmiček, ki se s havstoriji vrašča $\mathrm{v}$ les svojega gostitelja in iz njega črpa vodo z mineralnimi snovmi. Na mestih, kjer ohmelje s svojimi havstoriji prodira $\mathrm{v}$ gostitelja, nastane hipertrofija tkiva oziroma odebelitev, ki ima premer do $30 \mathrm{~cm}$. Deli vej nad odebelitvami pričnejo slabeti in odmirati. Za razliko od bele omele (Viscum album), ki je polparazitska zimzelena rastlina, je ohmelje listopadni grm (bela omela ima med drugim tudi nekoliko večje in debelejše - mesnate liste, zelenorumene upogljive poganjke, večinoma bele plodove in večje število gostiteljskih rastlin kot ohmelje). Najpogostejši gostitelji ohmelja so različne vrste hrastov, pojavlja se tudi na pravem kostanju (Castanea sativa) in zelo redko na navadni bukvi (Fagus sylvatica), belem gabru (Carpinus betulus), navadni brezi (Betula pendula) (Brus, 2005; Zebec in Idžojtić, 2006; Maček, 2008). Kot omenjeno, črpa ohmelje iz gostitelja vodo in mineralne snovi. Ker je intenzivnost transpiracije polparazita pogosto večja kot intenzivnost transpiracije gostitelja, vodni potencial $\mathrm{v}$ gostitelju pade. Visoka intenzivnost transpiracije naj bi bila za polparazita nujna, saj le tako lahko dobi zadostno količino mineralnih snovi za proizvodnjo lastne biomase (Schulze in sod., 1984; Treštić in sod., 2006). Grmi ohmelja imajo zaradi tega pri oskrbi z vodo in mineralnimi snovmi prednost pred gostiteljevimi asimilacijskimi površinami, drevo zato postopoma slabi, kmalu nastopi sušni stres, postaja pa tudi vse bolj dovzetno za druge škodljive organizme, ki prodirajo skozi štrclje odlomljenih vej.

Poleg ohmelja smo na gradnu v gozdu na Dularjevem bregu opazili tudi kostanjev rak, ki ga povzroča gliva Cryphonectria parasitica (slika 4). Okužba gradna z glivo C. parasitica je bila redka. Drevesa, poškodovana zaradi navadnega ohmelja, so bila oslabljena, skozi odmrle ali odlomljene veje so jih okužile glive, predvsem tiste, ki povzročajo trohnobo lesa (npr. plutač, Phellinus sp.). Odvzeli smo vzorce vej gradna, na katerih smo določili pet vrst gliv: Colpoma quercinum, Caudospora taleola, Coryneum elevatum, Valsa inter- 
media, Stereum sp. Za vse določene glive na vejah gradna je značilno, da postanejo patogene za hrast, ko je oslabljen; torej imajo sekundaren pomen.

Izdelali smo tudi dendrokronološko analizo iz koluta gradna, ki smo ga odvzeli na višini pol metra od tal. Analizirano drevo je imelo 176 branik in srednji premer 44,9 cm. Širine branik hrasta kažejo na postopno povečevanje širine branike do leta 1940. Sledi manjši upad širin branik, ki verjetno ni povezan z napadom polparazitske cvetnice. Ta upad traja do leta 1970, ko širina branik prvič pade pod dolgoletno povprečje (1,4 $\mathrm{mm})$. Po letu 1975 se začne izrazito upadanje širin branik, kar kaže na izrazito hiranje drevesa (slika 5). Značilnost obdobja med 1975 in 2008 je v postopnem izginjanju kasnega lesa v braniki in manjšanju števila vencev trahej v ranem lesu. Z analizo smo ugotovili, da je poleg sušnega rastišča na Dularjevem bregu problem tudi starost dreves, t. j. nad 170 let. V tej starosti je gradnu že močno upadla vitalnost in $s$ tem se mu je verjetno povečala občutljivost na okužbe z glivami ali na napade škodljivcev.

V opisanih razmerah obstajajo za izboljšanje stanja le gozdnogojitveni in gozdnogospodarski ukrepi. V prizadetem sestoju je potrebno dolgoročno zmanjšati delež gradna in ga nadomestiti s primernimi drevesnimi vrstami, ki so prilagojene na suha in topla rastišča: npr.

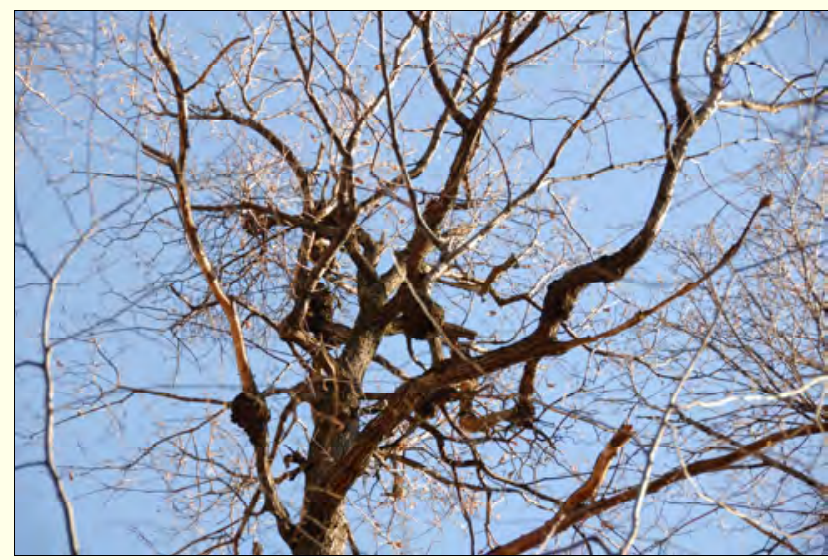

Slika 1: Posamezno drevo gradna je imelo tudi več kot 10 grmov navadnega ohmelja. lahko se poveča delež bukve, malega jesena, mokovca, črnega gabra in maklena.

\section{Viri}

Brus R. 2005. Dendrologija za gozdarje. Ljubljana, Univerza v Ljubljani, Biotehniška fakulteta, Oddelek za gozdarstvo in obnovljive gozdne vire: 408 str.

Maček J. 2008. Gozdna fitopatologija. Ljubljana, Zavod za gozdove Slovenije, Zveza gozdarskih društev Slovenije - Gozdarska založba: 448 str.

Schulze E.D., Turner N.C., Glatzel G. 1984. Carbon, water and nutrient relations of two mistletoes and their hosts: A hypothesis. Plant, Cell and Environment, 7: 293-299

Treštić T., Dautbašić M., Mujezinović O. 2006. Uticaj Hrastove imele (Loranthus europaeus Jacq.) na stabilnost sastojina hrasta kitnjaka. Works of the Faculty of Forestry, University of Sarajevo, 1: 8793

Zebec M., Idžojtić M. 2006. Hosts and distribution of yellow mistletoe (Loranthus europaeus Jacq.) in Croatia. Hladnikia, 19: 37-38

${ }^{1}$ Gozdarski inštitut Slovenije, Večna pot 2, 1000 Ljubljana; 2Zavod za gozdove Slovenije, Območna enota Ljubljana, Tržaška cesta 2, 1000 Ljubljana; 3Zavod za gozdove Slovenije, Krajevna enota Zagorje, Ul. 9. avgusta 78/a, 1410 Zagorje ob Savi

*nikica.ogris@gozdis.si

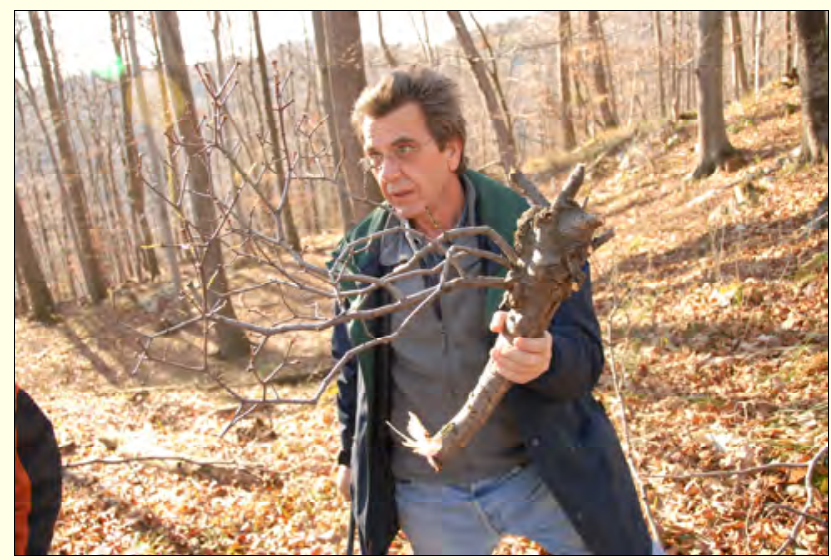

Slika 2: Grmi navadnega ohmelja so imeli premer do $1 \mathrm{~m}$. Na mestu, kjer so je navadno ohmelje izraščalo, je bila veja odebeljena. 


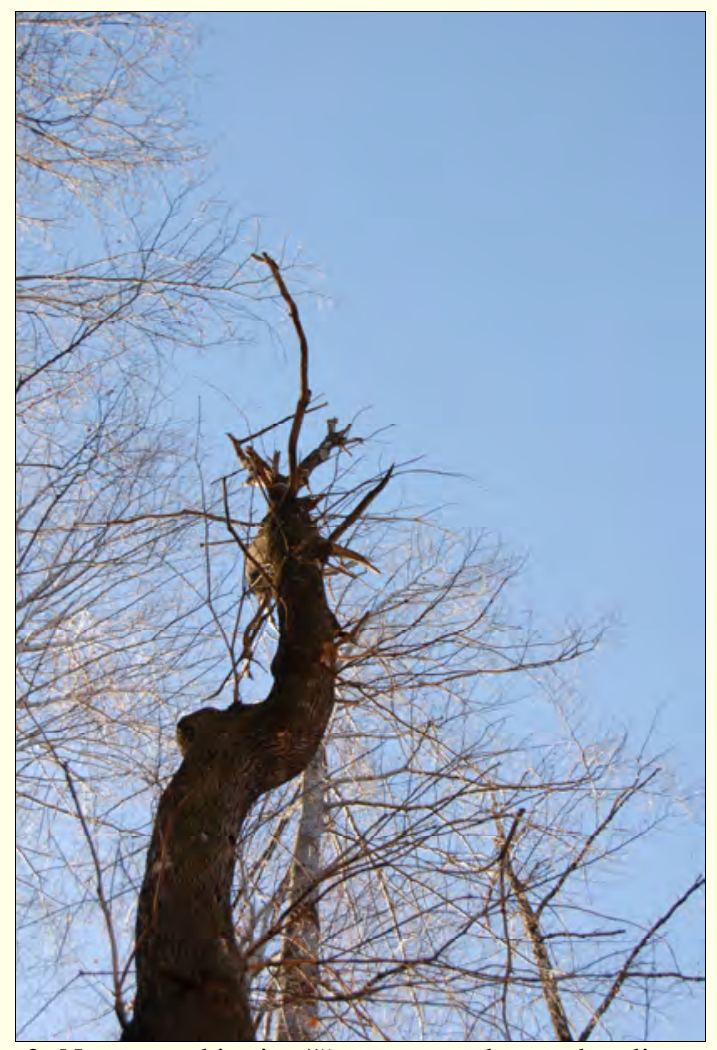

Slika 3: Na mestu, kjer izrašča grm navadnega ohmelja, se veja pogosto odlomi. Posledice so za drevo lahko tako drastične, da lahko ostane skoraj brez vej.

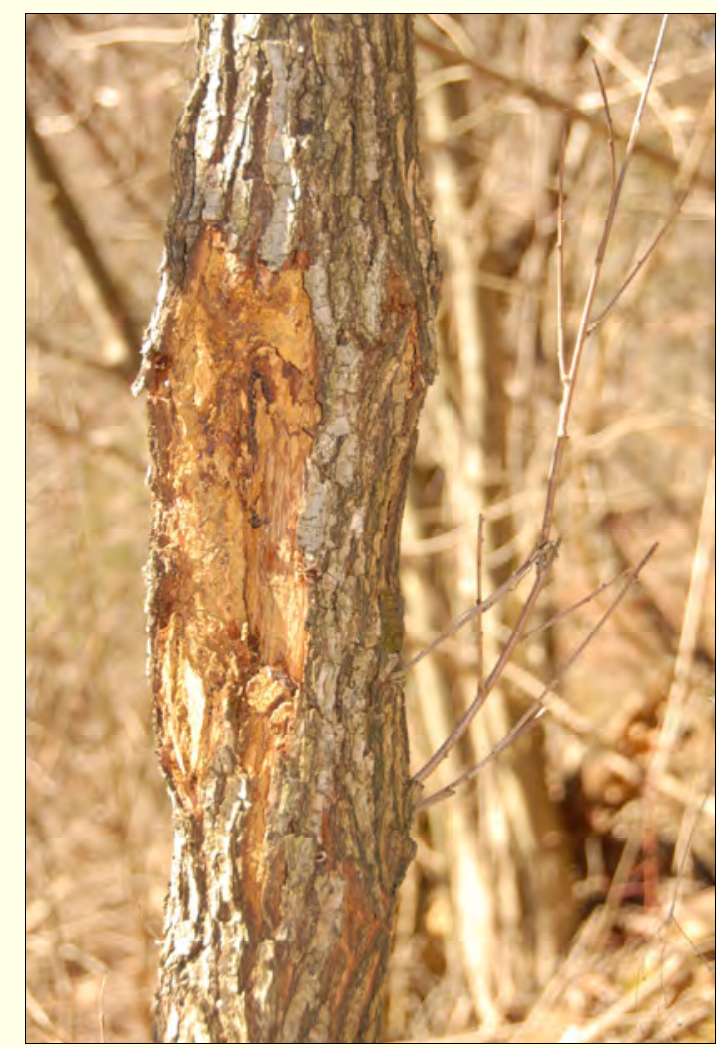

Slika 4: Graden je okužila gliva Chryphonectria parasitica, ki povzroča kostanjev rak.

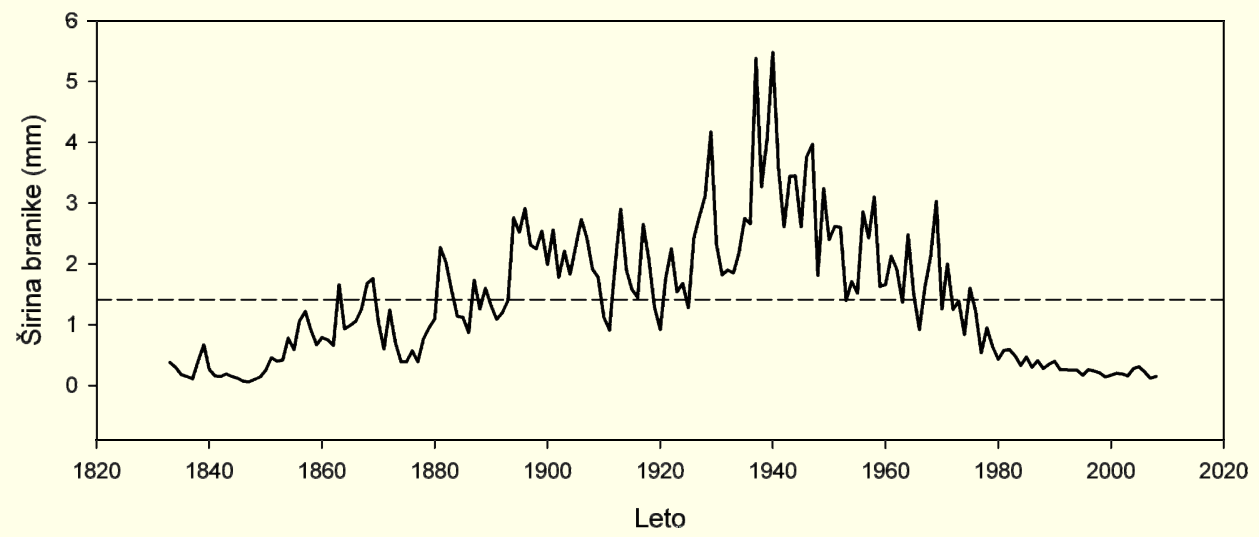

Slika 5: Širina branik za celotno življenjsko obdobje posekanega gradna na Dularjevem hribu (1832-2008).

\section{Rdeči bor se je začel sušiti po toči}

\section{Marija KOLŠEK ${ }^{1 *}$, Franc KOGOVŠEK ${ }^{2}$, Dušan JURC ${ }^{3}$}

Ob dolenjski avtocesti v smeri Ljubljana - Novo mesto severovzhodno od Grosuplja je dne 17. 6. 2010 kot oreh debela toča povzročila poškodbe na približno 60 ha gozda. Na neurje so najprej opominjale le razcefrane listne površine zelišč, grmovja in dreves. Ob koncu junija so na najbolj prizadetem območju začele rjaveti krošnje borov. Sušenje rdečega bora (Pinus sylvestris L.) je zaradi opazne lege ob avtocesti povzročilo veliko zanimanje oziroma zaskrbljenost javnosti.

Sušenje borov je povzročila zajedalska gliva, ki je okužila rane na skorji. Bori imajo v primerjavi z drugimi drevesnimi vrstami izredno veliko število splošno razširjenih in nevarnih glivičnih bolezni. Z izolacijo gliv v čisto kulturo smo ugotovili, da v ranah zaradi 